\section{$\checkmark$ Research Square}

Preprints are preliminary reports that have not undergone peer review.

They should not be considered conclusive, used to inform clinical practice, or referenced by the media as validated information.

\title{
Level of folic acid awareness for the prevention of neural tube defects and associated factors among pregnant women in Adama, South East Ethiopia
}

MESELECH AMBAW DESSIE ( $\sim$ mituababi@gmail.com )

University of Gondar College of Medicine and Health Sciences https://orcid.org/0000-0002-9186-8029 Ayanaw Worku Berihun

University of Gondar College of Medicine and Health Sciences

Research article

Keywords: Folic acid, Awareness, Neural tube defects

Posted Date: October 24th, 2019

DOI: https://doi.org/10.21203/rs.2.13117/v2

License: (c) (i) This work is licensed under a Creative Commons Attribution 4.0 International License.

Read Full License 


\section{Abstract}

Abstract Background: Neural tube defects are congenital anomalies of the brain, spinal cord, and their surrounding structures. Folic acid intake before and during the early weeks of pregnancy could reduce neural tube and other birth defects. Folic acid usage in the protective period of pregnancy against the neural tube defects is related to high level of awareness. This study aimed at evaluating the level of folic acid awareness for the prevention of neural tube defects and associated factors among pregnant women in Adama, South East Ethiopia. Method: A descriptive cross-sectional study design was used. 398 consented pregnant women attending antenatal care in Adama were the participants of the study. The women were selected by using a systematic random sampling method. A structured pre-tested interviewer-administered questionnaire was used to collect the data. The questionnaire was concerned with participants' demographic information, and their awareness about folic acid, roles of folic acid, and the recommended time of intake. Data were analyzed using SPSS version 20 statical software. Simple and multiple binary logistic regression analyses were conducted. 95\% confidence interval and p-value were used to evaluate the association between dependent and independent variables. Results: Of the interviewed women, $20.9 \%$ reported having heard or read something about folic acid supplements. But only $1.01 \%$ and $6.03 \%$ were aware of the recommended time of intake and the role of folic acid in preventing neural tube defects and other congenital anomalies respectively. The healthcare providers were the primary source of information about folic acid, which account $78.3 \%$. Folic acid awareness was associated with age, educational status, household monthly income, week of pregnancy at the first antenatal visit, any complication during current pregnancy, and use of folic acid during current pregnancy. Conclusions: Most of the pregnant women were not aware of folic acid, its importance and the recommended time of intake for preventing neural tube defects. Further effort is required from policymakers, healthcare providers, the media, and community to increase women's awareness about folic acid. Keywords: Folic acid, Awareness, Neural tube defects

\section{Background}

Neural tube defects (NTDs) are congenital anomalies of the brain, spinal cord, and their surrounding structures [1, 2]. NTDs are a source of high morbidity, distress, and severe physical, psychological, and social handicaps[3]. The impact of having a baby with spina bifida or losing a baby born with anencephaly is profound - emotionally, spiritually, and financially [4]. Most individuals who survive with NTDs have a multiple system handicaps and a limited life expectancy[5]. Stigmatization and discrimination may pose lifelong problems[6]. Anencephaly which accounts for about one-third of cases is incompatible with life while spina bifida, about two-thirds of NTDs, are associated with varying degrees of physical and mental disabilities even after treatment. Some of these are loss of bladder and bowel function, paralysis of the lower limbs, and hydrocephalus[7, 8]. The implications of this negative trend are the enormous physical, emotional, psychological, and financial burdens on the patients, the affected families, the caregivers, the healthcare system, and the community as a whole[2, 7]. 
Maternal folate status is involved in the pathogenesis of NTDs. Although the exact mechanism is not clear, a nutritional or genetic defect in homocysteine metabolism via methionine synthase appears likely[9]. In folate deficiency, homocysteine accumulates in the serum resulting in negative effects for health including increased risk of having a baby with NTD, increased risk of cardiovascular disease, and late pregnancy complications such as pre-eclampsia[10]. The deficiency of folic acid during pregnancy is also associated with the defects of the upper lip and mouth, urinary tract and limb morphology by disturbances in the nucleic acid synthesis and chromosomal breaks[8].

Foods that are good sources of folic acid include dark green vegetables, potatoes, beans, spinach, lentils, chickpeas, asparagus, broccoli, peas, brussel, sprouts, nuts, corn, liver, yeast, eggs, beans, oranges, banana and a wide range of fruits, as well as kidney beans $[1-3,11]$

Folic acid supplement one month before pregnancy and during first trimester of pregnancy could reduce NTD by $50-70 \%[1,8,12,13]$. Supplementation may also reduce other birth defects such as congenital cardiovascular defects, orofacial defect, limb defects, urinary tract anomalies, down syndrome, congenital hydrocephalus, omphalocele and imperforate anus[7, 14, 15].

Different studies explore that in order to encourage folic acid supplement use in pregnancy to prevent NTDs; it is vital to promote the awareness of women of childbearing age regarding the importance of folic acid in preventing NTDs and other congenital anomalies[2, 16]. In doing so, it is necessary to evaluate the level of awareness and predicting factors among pregnant women. Data reported from Turkey, India, Honduras, Nigeria, Australia, Lebanon, Europe, USA, United Arab Emirate, Taiwan and Iran range from $27.5 \%$ to $96.2 \%[1,7,9,12,13,17-23]$. Several factors seem to affect folic acid awareness for NTD prevention among women, such as age, educational status, household monthly income, and use of folic acid supplement $[7,20,23,24]$. In Ethiopia, there is no any official recommendation about preconceptional folic acid intake for NTD prevention. It is left to the judgment of the healthcare providers.

There is scant research on levels of folic acid awareness for prevention of NTDs and predicting factors among pregnant women in Ethiopia, particularly in Adama. The aim of this study was to assess the level of folic acid awareness and associated factors among pregnant women in Adama, South East Ethiopia.

\section{Methods}

\section{Study setting and period}

The study was conducted from August to November 2014 in two government health facilities, i.e. Adama Health Center and Adama Hospital Medical College located in Adama. These two heath facilities are commonly visited by pregnant women for antenatal care (ANC). Adama is a city located at $8.54^{\circ} \mathrm{N}$ $39.27^{\circ} \mathrm{E}$ at an elevation of 1712 meters, $99 \mathrm{~km}$ southeast of Addis Ababa. Based on the 2007 census conducted by the Central Statistical Agency of Ethiopia, this city has a total population of 220,212, of whom 111,340 were women. It was reported that the four largest ethnic groups in Adama were Oromo, 
Amhara, Gurage, and Silte. There are government hospitals and health centers in Adama that provides ANC follow up and other obstetric care free of charge[25].

\section{Study design and population}

An institution based descriptive cross-sectional study design was used. The study was conducted among women attending ANC. All pregnant women who visited Adama Health Center and Adama Hospital Medical College for ANC were included in the study.

\section{Sample size and sampling procedures}

\section{Data collection tools and study variables}

An original, structured, pre-tested questionnaire was prepared in English and translated into Amharic (local language) to the guardians then translated back to English. The Amharic version of the questionnaire was used to collect the data. The trained data collector administered the questionnaires to the subjects and conducted a face-to-face interviews with them to extract the required information. The questionnaire was concerned about sociodemographic variables, obstetric history, and awareness about folic acid and sources of information about folic acid supplements. The questions were aimed at women's awareness of folic acid in prevention of NTDs and other congenital anomalies and not about its role in anemia prevention. The assessment also included awareness about natural sources of folic acid, the importance of folic acid supplement, recommended time of intake for preventing NTDs, intake of folic acid supplements at some point during the current pregnancy, and previous history of a child with a birth defect. Women were grouped as aware if they report having heard and/or read about folic acid supplements. The household monthly income of the women was described using Ethiopian Birr (ETB).

The dependent variable was level of folic acid awareness for prevention of NTDs and the independent variables were age, educational status, marital status, household monthly income, occupation, number of pregnancies, number of antenatal visit, week of pregnancy at first ANC visit, gestational age at time of interview, history of unsuccessful pregnancy, history of a baby with a birth defect, presence of any complication during current pregnancy such as preeclampsia, any diagnosed chronic illness such as diabetes mellitus, hypertension, epilepsy, and use of folic acid during current pregnancy.

\section{Data analysis}

The data were entered to Epi Info version 7.2.1.0 and exported to SPSS version 20 statistical software. Data was double entered to check the consistency. Data were cleaned and edited before analysis. A simple and multiple binary logistic regression analyses were conducted using SPSS version 20 statistical software. Descriptive statistics were used to give a clear picture of the dependent and the independent variables.

The data were analyzed and a 95\% confidence interval, chi-square test, and P-value were used to check for the association between dependent and independent variables. A p-value of less than 0.05 was 
considered as statistically significant.a

\section{Results}

\section{Socio-demographic and obstetric characteristics of women}

A total 407 women were requested to participate in the study, but 9 of them were not voluntary and the final sample size becomes 398 . The participation rate was $97.8 \%$. More than half of the women (54.8\%) were at the age of 25 years and above(minimum was 16 years) and $96 \%$ of the women were married. About $37.7 \%$ of the women attended elementary and $33.4 \%$ attended high school. More than half of the women $(51.5 \%)$ had a monthly income between 1001 to 3000 ETB. $57.8 \%$ of the women were housewives (Table 1).

Among the interviewed women, $49 \%$ had $2-4$ pregnancy and $46.5 \%$ were primigravida. About $21.6 \%$ of the women came for their first ANC visit while $62.8 \%$ came for their $2^{\text {nd }}$ to $4^{\text {th }}$ visit. Gestational age at the first ANC visit was less than or equal to 12 weeks in $39.7 \%$ and greater than or equal to 25 weeks in $4.3 \%$ of the women. Most of the interviewed women (67.6\%) were in their third trimester. About $15.8 \%$ of the women had a previous history of unsuccessful pregnancy and $1 \%$ had a history of a baby with a birth defect. $6.3 \%$ of the women had complications during current pregnancy and $5.3 \%$ had a diagnosed chronic illness (Table 2).

\section{Folic acid awareness of women and associated factors}

Of the interviewed women, $20.9 \%$ (83/398) reported having heard or read something about folic acid supplements. Of those women, $91.6 \%$ (76/83) described folic acid in their own words. Folic acid was described by $5.3 \%(4 / 76)$ of the women as a supplement to prevent birth defects, including NTDs. About $62.7 \%(52 / 83)$ of the participant mentioned pregnant women as a group of people who needs to take folic acid supplements. Only about $6.1 \%(4 / 66)$ of the women stated one month before pregnancy and 3 months after pregnancy as recommended time of intake. When the women were asked about the importance of folic acid supplement intake, $37.9 \%$ (25/66) of them said it helps women to have a healthy baby, and $16.7 \%(11 / 66)$ of the women said it prevents NTDs. About $48.2 \%$ of women (192/398) reported they could identify natural folate-rich food and $24.4 \%$ correctly identified any of the correct natural sources of folic acid. The healthcare providers were a primary source of information about the folic acid supplement which accounts about 78.3\% (65/83). Table 3 shows the detail of folic acid awareness among women.

In the current study, folic acid awareness was significantly associated with age (OR=1.96, $\mathrm{Cl}=1.177$ 3.261), marital status $(\mathrm{OR}=1.054, \mathrm{Cl}=1.027-1.081)$, educational status $(\mathrm{OR}=6.914, \mathrm{Cl}=3.547-13.475$ and $\mathrm{p}$ value $=0.00)$, household monthly income $(\mathrm{OR}=0.449, \mathrm{Cl}=0.334-0.665$ and $\mathrm{p}$ value $=0.00)$, occupation $(\mathrm{OR}=$ $0.153, \mathrm{Cl}=0.032-0.734$ and $p$ value $=0.019)$, number of $A N C$ visit $(O R=0.485, C l=0.320-0.736$ and $p$ value $=0.001)$, week of pregnancy at first $A N C$ visit $(O R=2.756, C l=1.723-4.409$ and $p$ value $=0.00)$ and use of 
folic acid during current pregnancy $(\mathrm{OR}=0.139, \mathrm{Cl}=0.074-0.262$ and $\mathrm{p}$ value $=0.00 .0)$ on simple binary logistic regression.(Table 4)

On multiple logistic regression, applying enter method and considering all variables, age $(\mathrm{OR}=2.076, \mathrm{Cl}=1.009-4.244$ and $\mathrm{p}$ value $=0.04)$, educational status $(\mathrm{OR}=0.552, \mathrm{Cl}=0.324-0.941$ and $\mathrm{p}$ value $=0.02)$, household monthly income $(\mathrm{OR}=4.877, \mathrm{Cl}=1.120-21.24$ and $\mathrm{p}$ value $=0.03)$, week of pregnancy at first $A N C$ visit $(O R=1.999, \mathrm{Cl}=1.131-3.533$ and $p$ value $=0.01)$, any complication during current pregnancy $(\mathrm{OR}=26.642, \mathrm{Cl}=2.280-311.3$ and $p$ value $=0.009)$ and use of folic acid during current pregnancy $(\mathrm{OR}=0.147, \mathrm{Cl}=1.131-3.533$ and $\mathrm{p}$ value $=0.00)$ were found to be the predictors for folic acid awareness.(Table 4)

\section{Discussion}

Increased level of awareness about the role of folic acid supplement in preventing NTDs and other congenital anomalies and its recommended time of intake for women planning pregnancy and pregnant women is required in order to improve usage at the appropriate time[16]. Previously published report shows that only $1.9 \%$ of Ethiopian pregnant women use folic acid supplement at the recommended time to prevent NTD[26].

In the present study, $20.9 \%$ of the women had heard or read about folic acid supplement which was close to $27.5 \%$ of heard or read about folic acid in Turkey[1] but very low when compared to report of March of Dime and other studies[7-9, 12, 13, 17-20, 22, 27, 28](Table 5). Only $6.1 \%$ of the women mentioned pregnant women and/or women who plan to become pregnant as a group of people who need to take folic acid supplements. And only $1.01 \%$ of the entire study population knew the recommended time of folic acid intake to prevent NTD and other congenital anomalies. This finding was much lower than other studies conducted in a different time and different countries. It was reported that $30 \%$ in Honduran[22], $24.7 \%$ in Lebanon[13], $23.6 \%$ in Nigeria[1] and $19 \%$ in Turkey[1]. About $6.03 \%$ of the entire study participants were aware of the role of folic acid in preventing NTDs and other birth defects. This finding was also much lower than other studies: $26.9 \%$ in Nigeria[7], 26.2\% in Croatia[8], $15.4 \%$ and $27.6 \%$ in Iran [16, 17], 17\% in Europe[20], 14\% in Lebanon[13], 13\% in Turkey[1], 37.6\% in Honduras[9], 20\% in USA[27], and $46.6 \%$ in United Arab Emirates[19]. It is important to note that most of these countries have targeted women of childbearing age through national health awareness programs that have been implemented since the mid-1990s but it is not yet practiced in Ethiopia. In addition, birth defects are among the neglected diseases in Ethiopia. The policymakers, researchers, healthcare providers, and mass media are still not working on preventing birth defects. The women's low awareness about the role of folic acid in prevention of NTD and other birth defects reflect the ignorance of all stakeholders about NTD and other birth defects.

Nearly one fourth(24.4\%) of the study population correctly identified any of the correct natural source of folic acid, which was close to $26.5 \%$ in Nigeria[7] but less than $37.6 \%$ in Iran[17]. 
The primary source of information about folic acid in this study was found to be healthcare providers which was consistent with studies conducted in Nigeria, Iran, United Arab Emirate, Lebanon and Honduras $[7,13,17,19,22,24]$. But it was inconsistent with the study done in Turkey, where the primary sources of information were media and school[1]. Beyond its wide coverage mass media play a very weak role, which accounts only $8.4 \%$ of source of information that was extremely low as compared to $78.3 \%$ by healthcare providers who were limited in number and had limited contact with the community. Media accounts $14.6 \%$ in Nigeria[7], $17.8 \%$ in Iran[17] but only $8.4 \%$ in Ethiopia. Since media could address a wider range of people, it is necessary to emphasize more about health education programs on radio and television and health related articles in journals and magazines.

In our study, older age women were more likely to be aware of folic acid than younger women. This was consistent with the studies in Europe[20], Nigeria[7], United Arab Emirate[19] but in contrast to a study in Lebanon and Iran[13, 24]. Increased educational level was also positively associated with the awareness of the women, which was consistent with other studies done in USA[23], Iran[16, 24], United Arab Emirates[19], Honduras[22], Nigeria[7],Turkey[1] and Lebanon[13] and was contrasted to another study in Iran which reported no significant relationship exists between awareness and age and educational status[17]. The higher household monthly income was positively associated with folic acid awareness of the women like a study in Lebanon[13]. Early antenatal registration was positively associated with folic acid awareness which was consistent with the study in Iran[24]. The presence of any complication during current pregnancy like preeclampsia was negatively associated with awareness of the women. The use of folic acid during current pregnancy was also positively associated with awareness which was in contrast to a study in Taiwan, which stated no relationship exists between awareness and use of folic acid[18] (25).

The present study evaluates the awareness of women about the role of folic acid in preventing NTDs and other birth defects; identify the predicting factors for awareness of women and the primary sources of information about folic acid. These are helpful for policymakers, researchers, healthcare providers, and mass media. This study was conducted in Adama, Oromia Region; which is a big city where most of the people have access to a variety of health facilities and mass media. So it might not be concluded to women living in the rural areas. The study population was pregnant women attending ANC, so they may have a better awareness than women not attending ANC.

\section{Conclusions}

Most of the pregnant women were not aware of folic acid supplements; its importance and the recommended time of intake to prevent birth defects. Even though there are a lot of different types of media in Ethiopia, they have a few contributions on teaching women about folic acid and its importance in the prevention of birth defects. In order to improve folic acid supplement usage at the protective time for prevention of NTDs and other birth defects, further effort is required from policy maker, healthcare provider, media and community to start a folic acid awareness campaign. 


\section{List Of Abbreviations}

ANC: Antenatal care

Cl: Confidence interval

ETB: Ethiopian Birr

NTD: Neural tube defects

\section{Declarations}

\section{Ethical approval and consent to participate}

The study was conducted after ethical clearance letters obtained from the University of Gondar, College of Medicine and Health Science, School of Medicine ethical committee. Informed verbal consent was taken from the study participant. The objective of this research was explained to the study participant's after that, those willing to participate were included. The study participants were free in answering the questionnaire or withdraw from the study at any time. The verbal consent was obtained over the written consent because most of Ethiopian consider signing on any paper as taking responsibility and fear of being cheated after signing on any document which is not their own business. So we use verbal consent to facilitate the data collection. The ethical committee has approved it.

Consent for publication: Not applicable

\section{Availability of the data}

The datasets generated and analyzed in the current study are available from the corresponding author on reasonable request.

\section{Competing interests}

The authors declare that there is no competing interest.

\section{Funding}

This research has been funded by the University of Gondar, College of Medicine and Health Science. The university gives a grant in order to conduct the study but have no any role in study design; collection, analysis, and interpretation of data; writing the report; and the decision to submit the report for publication.

\section{Authors' contributions}

MA: conceive the study, develop the proposal, collected data, analyze and interpret data, wrote the draft of the manuscript, revised the draft of the manuscript critically 
AW: supervised the collection of data, revised the draft of the manuscript

Both authors read and approve the read and approved the final version of the manuscript.

\section{Acknowledgments}

I honestly acknowledge administration and the staffs of Adama hospital medical college and Adama health center for their kind cooperation during the data collection time.

\section{Authors' information}

${ }^{1}$ BSc In Public Health Officer and MSc in Human Anatomy, Lecturer at Department of Anatomy, School of Medicine, College of Medicine and Health Science, University of Gondar, Gondar, Ethiopia.

${ }^{2} \mathrm{BSc}$ in Nursing and MSc in Human Anatomy Department of Human Anatomy, School of Medicine, College of Medicine and Health Science, University of Gondar, Gondar, Ethiopia

\section{References}

1. Unusan N: Assessment of Turkish Women's Knowledge Concerning Folic Acid and Prevention of Birth Defects. Public Health Nutrition 2004, 7(7):851-855.

2. D. Rofail AC, L. Abetz, M. Lindemann, L. Maguire: Factors contributing to the success of folic acid public health campaigns. Journal of Public Health 2011, 34(1):90-99.

3. Nelson AL: Folates for Reduction of Risk of Neural Tube Defects: Using Oral Contraceptives as a Source of Folate. Open Access Journal of Contraception 2011, 2137-150.

4. Folic Acid and Pregnancy

5. Greene NDE, Stanier P, Copp AJ: Genetics of Human Neural Tube Defects. Human Molecular Genetics 2009, 18(2):113-129.

6. De-Regil L, Fernández-Gaxiola A, Dowswell T, Peña-Rosas J: Effects and Safety of Periconceptional Folate Supplementation for Preventing Birth Defects (Review). In. Edited by Collaboration TC, vol. 10. The Cochrane Library: JohnWiley \& Sons, Ltd.; 2010.

7. Anzaku AS: Assessing Folic Acid Awareness and its Usage for the Prevention of Neural Tube Defects among Pregnant Women in Jos, Nigeria. Journal of Basic and Clinical Reproductive Sciences 2013, 2(1):13-17.

8. Vitale K, Mujki A, Todorovi G, Tulchinsky TH: Is level of knowledge, attitude and use of folic acid among pregnant women in Croatia a call for public health action? PERIODICUM BIOLOGORUM 2009, 111(3):329-335,

9. Milla GR, Flores AL, Umaña E, Mayes I, Rosenthal J: Postpartum women in the Honduran health system: folic acid knowledge, attitudes, and practices. Pan Am J Public Health 2007, 22(5):340-347. 
10. De-Regil LM F-GA, Dowswell T, Peña-Rosas JP: Effects and safety of periconceptional folate supplementation for preventing birth defects (Review). In. Edited by Collaboration TC, vol. 10. The Cochrane Library: JohnWiley \& Sons, Ltd.; 2010.

11. Dr.Kurian Deepti DHA, Dr.Chakraborty Arup , Dr. Balraj Vinohar: Determinants of knowledge regarding folic acid in periconceptional use among pregnant mothers in Southern India. Journal of Dental and Medical Sciences (IOSR-JDMS) 2013, 4(3):25-29.

12. Bowera C, Millera M, Paynea J, Serna P: Promotion of Folate for the Prevention of Neural Tube Defects: Who Benefits? Paediatric and Perinatal Epidemiology 2005, 19(6):435-444.

13. Hage CN, Jalloul M, Sabbah M, Adib SM: Awareness and Intake of Folic Acid for the Prevention of Neural Tube Defects Among Lebanese Women of Childbearing Age. Maternal and Child Health Journal 2012, 16(1):258-265.

14. Bailey LB, Berry RJ: Folic acid supplementation and the occurrence of congenital heart defects, orofacial clefts, multiple births, and miscarriage. Am J Clin Nutr 2005, 81(suppl):1213S-1217S.

15. Czeize AE: The primary prevention of birth defects: Multivitamins or folic acid? Int J Med Sci 2004, 1(1):50-61.

16. Mashayekhi SO, Dilmaghanizadeh M, Sattari MR: A Survey on the Consumption, Knowledge and Attitude of Pregnant Women toward the Effects of Folic Acid on Pregnancy Outcome in Tabriz. Iran J Child Neurology 2011, 5(1):35-42.

17. Nosrat SB, Sedehi M, Golalipour MJ: Knowledge and practice of urban Iranian pregnant women towards folic acid intake for neural tube defect prevention. J Pak Med Assoc 2012, 62(8):785-789.

18. Jou H, Hsu I, Liu C, Chung S, Chen S, Gau M: Awareness and use of folic acid among pregnant women in Taipei. Taiwan J Obstet Gynecol 2010, 49(3):306-310.

19. Al-Hossani H, Abouzeid H, Salah MM, Farag HM, Fawzy E: Knowledge and Practices of Pregnant Women About Folic Acid in Pregnancy in Abu Dhabi, United Arab Emirates. Eastern Mediterranean Health Journal 2010, 16 (4):402-407.

20. Bitzer J, Stenglin Av, Bannemerschult R: Women's Awareness and Periconceptional Use of folic acid: Data from a Large European Survey. International Journal of Women's Health 2013, 5 201-213.

21. Deepti K, Anila H, Arup C, Vinohar B: Determinants of Knowledge Regarding Folic Acid in Periconceptional Use among Pregnant Mothers in Southern India. Journal of Dental and Medical Sciences 2013, 4(3):25.29.

22. Wu DY, Brat G, Milla G, Kima J: Knowledge and use of folic acid for prevention of birth defects amongst Honduran women. Reproductive Toxicology 2007, 23 (2007):600-606.

23. Chacko MR, Anding R, Kozinetz CA, Grover JL, B.Smith P: Neural Tube Defects: Knowledge and Preconceptional Prevention Practices in Minority Young Women. Pediatrics 2003, 112(3):536-541.

24. Riazi H, Bashirian S, Amini L: Awareness of Pregnant Women about Folic Acid Supplementation in Iran. Journal of Family and Reproductive Health 2012 6(4):159-163.

25. Adama's Location with in Ethiopia 
26. Dessie MA, Zeleke EG, Workie SB, Berihun AW: Folic acid usage and associated factors in the prevention of neural tube defects among pregnant women in Ethiopia: cross-sectional study. $B M C$ Pregnancy and Childbirth 2017, 17(313).

27. Gallup: Improving Preconception Health: Women's Knowledge and Use of Folic Acid. In. USA: March of Dimes Foundation, White Plains, NY; 2008.

28. Eghwrudjakpor P, Amadi C, Amusan E: Evaluation of the Level of Awareness of the Role Of Folic Acid in The Prevention of Neural Tube Defects Amongst Women Of Reproductive Age In A Tertiary Health Institution. Nigerian Journal of Medicine 2011, 20(2):207-212.

\section{Tables}

Table 1: Socio-demographic characteristics of the women attending ANC in Adama, South East Ethiopia N=398

\begin{tabular}{|c|c|c|c|}
\hline Variables & & Frequency $(\mathrm{N}=398)$ & Percent \\
\hline \multirow[t]{2}{*}{ Age } & $<25$ years & 180 & 45.2 \\
\hline & $\geq 25 y e a r s$ & 218 & 54.8 \\
\hline \multirow[t]{2}{*}{ Marital status } & Non-married & 16 & 4 \\
\hline & Married & 382 & 96 \\
\hline \multirow[t]{4}{*}{ Educational status } & No formal education & 34 & 8.5 \\
\hline & Attend elementary school & 150 & 37.7 \\
\hline & Attend high school & 133 & 33.4 \\
\hline & $\begin{array}{lll}\begin{array}{l}\text { College } \\
\text { degrees }\end{array} & & \\
\end{array}$ & 81 & 20.4 \\
\hline \multirow{4}{*}{$\begin{array}{l}\text { Household } \\
\text { income }\end{array}$} & $<1000$ & 84 & 21.1 \\
\hline & $1001-3000$ & 205 & 51.5 \\
\hline & $3001-5000$ & 78 & 19.6 \\
\hline & 5001 and above & 31 & 7.8 \\
\hline \multirow[t]{5}{*}{ Occupation } & Housewife & 230 & 57.8 \\
\hline & Professional worker & 69 & 17.3 \\
\hline & Skilled worker & 75 & 18.8 \\
\hline & Day laborer & 10 & 2.5 \\
\hline & Other(student, jobless) & 14 & 3.5 \\
\hline
\end{tabular}

Table 2: Obstetric characteristic of the women attending ANC in Adama, South East Ethiopia $\mathbf{N}=398$ 


\begin{tabular}{|l|l|l|l|}
\hline Variable & & Frequency(N=398) & Percent \\
\hline \multirow{4}{*}{ Number of pregnancy } & Primigravida & 185 & 46.5 \\
\cline { 2 - 4 } & $2-4$ & 195 & 49.0 \\
\cline { 2 - 4 } & $\geq 5$ & 18 & 4.5 \\
\hline \multirow{4}{*}{ Number of ANC visit } & First visit & 86 & 21.6 \\
\cline { 2 - 4 } & $2-4$ & 250 & 62.8 \\
\cline { 2 - 4 } & $>4$ & 62 & 15.6 \\
\hline \multirow{4}{*}{ Week of pregnancy at 1 ${ }^{\text {st }}$ ANC visit } & $\leq 12$ & 158 & 39.7 \\
\cline { 2 - 4 } & $13-24$ & 223 & 56.0 \\
\cline { 2 - 4 } & $\geq 25$ & 17 & 4.3 \\
\hline Gestational age at time of interview & $\leq 12$ & 19 & 27.6 \\
\cline { 2 - 4 } & $13-24$ & 110 & 67.6 \\
\cline { 2 - 4 } & $\geq 25$ & 269 & \\
\hline
\end{tabular}

Table 3: Folic acid awareness and associated factors among pregnant women attending ANC in Adama, South East Ethiopia N=398 


\begin{tabular}{|c|c|c|c|}
\hline Variable & & $\begin{array}{l}\text { Frequency } \\
(\mathrm{N}=398)\end{array}$ & Percent \\
\hline \multirow{2}{*}{$\begin{array}{l}\text { Ever heard and/read } \\
\text { something called folic } \\
\text { supplement }\end{array}$} & Yes & 83 & 20.9 \\
\hline & No & 315 & 79.1 \\
\hline \multirow{2}{*}{$\begin{array}{l}\text { If yes could you describe folic acid } \\
\text { supplement }(\mathrm{N}=83)\end{array}$} & Yes & 76 & 91.6 \\
\hline & No & 7 & 8.4 \\
\hline \multirow[t]{5}{*}{$\begin{array}{lcccc}\text { How } & \text { do } & \text { you } & \text { describe } & \text { folic } \\
\operatorname{acid}(\mathrm{N}=76) & & & \end{array}$} & $\begin{array}{l}\text { A supplement to prevent } \\
\text { birth defects }\end{array}$ & 4 & 5.3 \\
\hline & $\begin{array}{l}\text { A medication to prevent } \\
\text { anemia }\end{array}$ & 38 & 50.0 \\
\hline & $\begin{array}{l}\text { A supplement for the } \\
\text { health of baby and } \\
\text { mother }\end{array}$ & 23 & 30.3 \\
\hline & It is just vitamin & 7 & 9.2 \\
\hline & Other & 4 & 5.3 \\
\hline \multirow{5}{*}{$\begin{array}{l}\text { Group of people who need to take a } \\
\text { folic acid supplement }(\mathrm{N}=83)\end{array}$} & Pregnant women & 52 & 62.7 \\
\hline & $\begin{array}{l}\text { Women plan to become } \\
\text { pregnant }\end{array}$ & 4 & 4.81 \\
\hline & Both & 10 & 12.0 \\
\hline & $\begin{array}{l}\text { Other( Post-partum } \\
\text { women, children, all ) }\end{array}$ & 4 & 4.81 \\
\hline & I don't know & 13 & 15.7 \\
\hline \multirow{8}{*}{$\begin{array}{l}\text { Recommended time for taking a folic } \\
\text { acid supplement }(\mathrm{N}=66)\end{array}$} & Before pregnancy & 7 & 10.61 \\
\hline & $\begin{array}{l}\text { When they discover they } \\
\text { are pregnant }\end{array}$ & 15 & 22.73 \\
\hline & During the first trimester & 10 & 15.15 \\
\hline & During the $2^{\text {nd }}$ trimester & 14 & 21.21 \\
\hline & During the $3^{\text {rd }}$ trimester & 3 & 4.55 \\
\hline & $\begin{array}{l}1 \quad \text { month } \quad \text { before } \\
\text { pregnancy and } 3 \text { months } \\
\text { after pregnancy }\end{array}$ & 4 & 6.06 \\
\hline & I don't know & 8 & 12.12 \\
\hline & 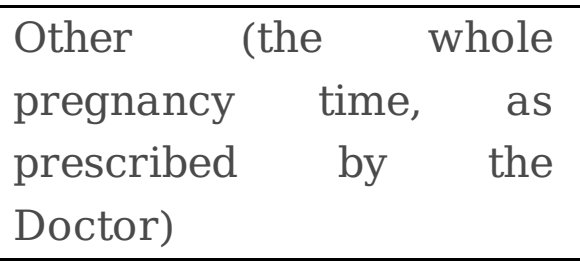 & 5 & 7.58 \\
\hline Importance of folic acid supplement & Helps to ensure women & 25 & 37.88 \\
\hline
\end{tabular}




\begin{tabular}{|c|c|c|c|}
\hline \multirow{6}{*}{$\begin{array}{l}\text { for pregnant/plan to become } \\
\text { pregnant women }(\mathrm{N}=66)\end{array}$} & \multicolumn{3}{|l|}{ to have a healthy baby } \\
\hline & \multirow{2}{*}{$\begin{array}{l}\text { It prevents NTDs } \\
\text { Decrease the risk of BD }\end{array}$} & 11 & 16.67 \\
\hline & & 13 & 19.7 \\
\hline & $\begin{array}{l}\text { To avoid labor } \\
\text { complications }\end{array}$ & 7 & 10.61 \\
\hline & I don't know & 6 & 9.09 \\
\hline & $\begin{array}{l}\text { Other(to treat and } \\
\text { prevent anemia) }\end{array}$ & 4 & 6.06 \\
\hline \multirow{2}{*}{$\begin{array}{l}\text { Do you know food/and drink that are } \\
\text { rich in folic acid }\end{array}$} & Yes & 192 & 48.2 \\
\hline & No & 206 & 51.8 \\
\hline \multirow[t]{2}{*}{$\begin{array}{l}\text { Food that are good source of folic } \\
\text { acid }(N=192)\end{array}$} & $\begin{array}{l}\text { Correctly identified any } \\
\text { source }\end{array}$ & 97 & 24.4 \\
\hline & Not correct & 391 & 75.6 \\
\hline \multirow[t]{4}{*}{ Source of information $(\mathrm{N}=83)$} & $\begin{array}{lll}\begin{array}{l}\text { Friends } \\
\text { members }\end{array} & \text { Family } \\
\end{array}$ & 3 & 3.6 \\
\hline & Health care provider & 65 & 78.3 \\
\hline & Mass media & 7 & 8.4 \\
\hline & Profession & 8 & 9.64 \\
\hline \multirow{2}{*}{$\begin{array}{l}\text { Did you take folic acid for current } \\
\text { pregnancy }(\mathrm{N}=398)\end{array}$} & Yes & 205 & 51.5 \\
\hline & No & 193 & 48.5 \\
\hline
\end{tabular}

Table 4: Association between the level of folic acid awareness for NTD prevention and predicting factors among pregnant women $\mathrm{N}=398$ 


\begin{tabular}{|c|c|c|c|c|c|c|}
\hline & \multicolumn{2}{|c|}{$\begin{array}{l}\text { Awareness about folic } \\
\text { acid }\end{array}$} & \multirow{2}{*}{$\begin{array}{l}\text { Crude odds } \\
\text { ratio with } \\
95 \% \text { CI }\end{array}$} & \multirow{2}{*}{$\begin{array}{l}\text { Adjusted } \\
\text { odds ratio } \\
\text { with } 95 \% \text { CI }\end{array}$} & \multirow[t]{2}{*}{$\begin{array}{l}\mathrm{P} \\
\text { values }\end{array}$} \\
\hline & & Yes & No & & & \\
\hline & Age $<25$ & $27(15.0 \%)$ & $153(85.0 \%)$ & \multirow{2}{*}{$\begin{array}{l}1.96(1.177- \\
3.261)\end{array}$} & \multirow{2}{*}{$\begin{array}{l}2.076(1.009- \\
4.244)\end{array}$} & \multirow{2}{*}{$\begin{array}{l}0.01 * \\
0.04^{* *}\end{array}$} \\
\hline & Age $\geq 25$ & $56(25.7 \%)$ & $162(74.3 \%)$ & & & \\
\hline & Married & 83 & 299 & \multirow{2}{*}{$\begin{array}{l}1.054(1.027- \\
1.081)\end{array}$} & \multirow{2}{*}{$\begin{array}{l}2.8(0.00- \\
0.55)\end{array}$} & \multirow{2}{*}{$\begin{array}{l}0.998 * \\
0.998 * *\end{array}$} \\
\hline & $\begin{array}{l}\text { Non- } \\
\text { married }\end{array}$ & 0 & 16 & & & \\
\hline \multirow[t]{4}{*}{ onal } & $\begin{array}{l}\text { No formal } \\
\text { education }\end{array}$ & $0(0 \%)$ & $34(100 \%)$ & \multirow[t]{4}{*}{$\begin{array}{l}\text { 6.914(3.547- } \\
13.475)\end{array}$} & \multirow[t]{4}{*}{$\begin{array}{l}0.552(0.324- \\
0.941)\end{array}$} & \multirow[t]{4}{*}{$\begin{array}{l}0.00^{*} \\
0.02 * *\end{array}$} \\
\hline & $\begin{array}{l}\text { Attend } \\
\text { elementary }\end{array}$ & $17(11.3 \%)$ & 133(88.7\%) & & & \\
\hline & $\begin{array}{l}\text { Attend high } \\
\text { school }\end{array}$ & $28(21.1 \%)$ & $105(78.9 \%)$ & & & \\
\hline & $\begin{array}{l}\text { College } \\
\text { diploma and } \\
\text { degrees }\end{array}$ & $38(46.9 \%)$ & $43(53.1 \%)$ & & & \\
\hline \multirow{4}{*}{$\begin{array}{l}\text { old } \\
\text { by }\end{array}$} & $\leq 1000$ & $6(7.1 \%)$ & 78(92.2\%) & \multirow{4}{*}{$\begin{array}{l}0.449(0.334- \\
0.665)\end{array}$} & \multirow{4}{*}{$\begin{array}{l}4.877(1.120- \\
21.24)\end{array}$} & \multirow{4}{*}{$\begin{array}{l}0.00^{*} \\
0.03^{* *}\end{array}$} \\
\hline & $1001-3000$ & $37(18.0)$ & $168(82.0 \%)$ & & & \\
\hline & $3001-5000$ & $25(32.1)$ & $53(67.9 \%)$ & & & \\
\hline & $>5000$ & $15(48.4 \%)$ & 16(51.6\%) & & & \\
\hline \multirow[t]{5}{*}{ tion } & Housewife & $28(12.2 \%)$ & $202(87.8)$ & \multirow{5}{*}{$\begin{array}{l}0.153(0.032- \\
0.734)\end{array}$} & \multirow{5}{*}{$\begin{array}{l}2.014(0.282- \\
14.395)\end{array}$} & \multirow{5}{*}{$\begin{array}{l}0.019 * \\
0.485 * *\end{array}$} \\
\hline & $\begin{array}{l}\text { Professional } \\
\text { worker }\end{array}$ & $36(52.2 \%)$ & $33(47.8 \%)$ & & & \\
\hline & $\begin{array}{l}\text { Skilled } \\
\text { worker }\end{array}$ & $17(22.7 \%)$ & $58(77.3 \%)$ & & & \\
\hline & Day laborer & $0(0 \%)$ & $10(100 \%)$ & & & \\
\hline & Student & $2(14.3 \%)$ & $12(85.7 \%)$ & & & \\
\hline \multirow{3}{*}{ of } & Primigravida & $36(19.5 \%)$ & $149(80.5 \%)$ & \multirow{3}{*}{$\begin{array}{l}1.008(0.663- \\
1.532)\end{array}$} & \multirow{3}{*}{$\begin{array}{l}1.051(0.66- \\
16.782)\end{array}$} & \multirow{3}{*}{$\begin{array}{l}0.97 * \\
0.972 * *\end{array}$} \\
\hline & $2-4$ & $46(23.6 \%)$ & $149(76.4 \%)$ & & & \\
\hline & $>4$ & $1(5.6 \%)$ & $17(94.4 \%)$ & & & \\
\hline \multirow{3}{*}{ of } & First visit & $7(8.1 \%)$ & $79(91.9 \%)$ & \multirow{3}{*}{$\begin{array}{l}0.485(0.320- \\
0.736)\end{array}$} & \multirow{3}{*}{$\begin{array}{l}0.751(0.143- \\
3.957)\end{array}$} & \multirow{3}{*}{$\begin{array}{l}0.001 * \\
0.736 * *\end{array}$} \\
\hline & $2^{\text {nd }}-4^{\text {th }}$ visit & $57(22.8 \%)$ & 193(77.2\%) & & & \\
\hline & $>4$ visit & $19(30.6 \%)$ & $43(69.4 \%)$ & & & \\
\hline \multirow{3}{*}{$\begin{array}{l}\text { of } \\
\text { Icy } \\
\text { ANC }\end{array}$} & $\leq 12$ & $49(31.0 \%)$ & $109(69.0 \%)$ & & 1.999(1.131- & $0.00 *$ \\
\hline & $13-24$ & $34(15.2 \%)$ & $189(84.8)$ & $4.409)$ & 3.533) & $0.01 * *$ \\
\hline & $\geq 25$ & $0(0.0 \%)$ & $17(100 \%)$ & & & \\
\hline
\end{tabular}




\begin{tabular}{|c|c|c|c|c|c|c|}
\hline \multirow{3}{*}{$\begin{array}{l}\text { nal } \\
\text { time } \\
\text { view }\end{array}$} & $\leq 12$ & $2(10.5 \%)$ & 17(89.5\%) & \multirow{3}{*}{$\begin{array}{l}0.670(0.420- \\
1.069)\end{array}$} & \multirow{3}{*}{$\begin{array}{l}3.751(0.511- \\
27.503)\end{array}$} & \multirow{3}{*}{$\begin{array}{l}0.093^{*} \\
0.193^{* *}\end{array}$} \\
\hline & $13-24$ & $19(17.3 \%)$ & $91(82.7 \%)$ & & & \\
\hline & $\geq 25$ & $62(23.0)$ & $207(77.0 \%)$ & & & \\
\hline \multirow{2}{*}{$\begin{array}{l}\quad \text { of } \\
\text { !ssful } \\
\text { Icy } \\
\text { ime }\end{array}$} & Yes & $13(20.6 \%)$ & $50(79.4 \%)$ & \multirow[t]{2}{*}{$\begin{array}{l}1.016(0.523- \\
1.975)\end{array}$} & \multirow[t]{2}{*}{$\begin{array}{l}2.036(0.764- \\
5.425)\end{array}$} & \multirow[t]{2}{*}{$\begin{array}{l}0.963 * \\
0.155 * *\end{array}$} \\
\hline & No & $70(20.9 \%)$ & $265(79.1 \%)$ & & & \\
\hline \multirow{2}{*}{$\begin{array}{l}\text { of a } \\
\text { with } \\
\text { fect }\end{array}$} & Yes & $1(25.0 \%)$ & $3(75.0 \%)$ & \multirow{2}{*}{$\begin{array}{l}0.788(0.081- \\
7.679)\end{array}$} & \multirow{2}{*}{$\begin{array}{l}0.825(0.40- \\
16.893)\end{array}$} & \multirow{2}{*}{$\begin{array}{l}0.838 * \\
0.901 * *\end{array}$} \\
\hline & No & $82(20.8 \%)$ & $312(79.2 \%)$ & & & \\
\hline \multirow[t]{2}{*}{ ation } & Yes & $1(4.0 \%)$ & $24(96.0 \%)$ & \multirow[t]{3}{*}{$\begin{array}{l}6.763(0.901- \\
50.743)\end{array}$} & \multirow[t]{3}{*}{$\begin{array}{l}26.642(2.280- \\
311.354)\end{array}$} & \multirow[t]{3}{*}{$\begin{array}{l}0.063 * \\
0.009 * *\end{array}$} \\
\hline & No & $82(22.0 \%)$ & $291(78.0 \%)$ & & & \\
\hline \multirow[t]{3}{*}{ icy } & & & & & & \\
\hline & Yes & $5(23.8 \%)$ & $16(76.2 \%)$ & \multirow{2}{*}{$\begin{array}{l}0.835(0.297- \\
2.349)\end{array}$} & \multirow{2}{*}{$\begin{array}{l}0.973(0.252- \\
3.760)\end{array}$} & \multirow{2}{*}{$\begin{array}{l}0.732^{*} \\
0.968^{* *}\end{array}$} \\
\hline & No & $78(20.7 \%)$ & $299((79.3)$ & & & \\
\hline \multirow[t]{2}{*}{ folic } & Yes & $70(34.1 \%)$ & $135(65.9 \%)$ & \multirow{2}{*}{$\begin{array}{l}0.139(0.074- \\
0.262)\end{array}$} & \multirow{2}{*}{$\begin{array}{l}0.131(0.054- \\
0.318)\end{array}$} & \multirow{2}{*}{$\begin{array}{l}0.000 * \\
0.000 * *\end{array}$} \\
\hline & No & $13(6.7 \%)$ & 183(93.3\%) & & & \\
\hline
\end{tabular}

*p values at simple logistic regression

**p values at multiple logistic regression

Table 5: comparisons of the level of folic acid awareness among women from a different countries and different kinds of literature 


\begin{tabular}{|c|c|c|c|c|}
\hline Irs & $\begin{array}{l}\text { Sample } \\
\text { size }\end{array}$ & $\begin{array}{lrr}\text { Level of folic } & \text { acid } \\
\text { awareness } & & \\
\end{array}$ & Study area & $\begin{array}{l}\text { Study } \\
\text { year }\end{array}$ \\
\hline ru & 543 & $64.6 \%$ & Nigeria & 2012 \\
\hline $\mathrm{an}$ & 818 & $27.5 \%$ & Turkey & 2002 \\
\hline$\overline{\text { et al }}$ & 2619 & $46.4 \%$ & Honduras & 2000 \\
\hline et al & 600 & $60 \%$ & Lebanese & 2008 \\
\hline tet al & 676 & $96.2 \%$ & Iran & 2008 \\
\hline al & 275 & $90.0 \%$ & Taiwan & 2008 \\
\hline ani et al & 277 & $79.1 \%$ & $\begin{array}{l}\text { United Arab } \\
\text { Emirates }\end{array}$ & - \\
\hline et al & 22,925 & $70.0 \%$ & $\begin{array}{ll}18 & \text { European } \\
\text { countries } & \\
\end{array}$ & 2009 \\
\hline al & 508 & $45 \%$ & Honduras & 2004 \\
\hline swer et & 578 & $62.3 \%$ & Australia & $\begin{array}{l}1997- \\
2000\end{array}$ \\
\hline et al & 322 & $73.6 \%$ & Iran & - \\
\hline $\mathrm{p}$ & 2003 & $84 \%$ & USA & 2008 \\
\hline so et al & 434 & $52 \%$ & USA & $\begin{array}{l}1999- \\
2000\end{array}$ \\
\hline et al & 609 & 44.8 & Croatia & 2004 \\
\hline
\end{tabular}

\section{Supplementary Files}

This is a list of supplementary files associated with this preprint. Click to download.

- Additionalfile.pdf 